\title{
THE ROLE OF POWER GENERATION TECHNOLOGY IN MITIGATING GLOBAL CLIMATE CHANGE
}

\author{
FRANK PRINCIOTTA $\dagger$
}

\begin{abstract}
Anthropogenic emissions of greenhouse gases, especially carbon dioxide, $\mathrm{CO}_{2}$, have led to increasing atmospheric concentrations which are mostly responsible for the roughly $0.8^{\circ} \mathrm{C}$ global warming the Earth has experienced since the Industrial Revolution. With industrial activity and population expected to increase throughout the rest of the century, large increases in greenhouse gas emissions are projected, with additional and potentially substantial subsequent global warming predicted. Using a powerful PC-based global climate model, global warming is projected for two business as usual cases, as well as simple yet instructive scenarios in which major programs are initiated to limit $\mathrm{CO}_{2}$ emissions. This paper provides a brief overview of the forces driving $\mathrm{CO}_{2}$ emissions, how different $\mathrm{CO}_{2}$ emission trajectories could affect temperature this century, with a focus on power generation mitigation options, and research and development priorities. While much literature exists on various aspects of this subject, this paper aims to provide a succinct integration of our best knowledge of the projected warming the Earth is likely to experience in the decades ahead, the emission reductions that may be needed to constrain this warming to tolerable levels, and the technologies potentially available to help achieve these emission reductions.
\end{abstract}

\section{INTRODUCTION}

In February 2007, the Intergovernmental Panel on Climate Change (IPCC) concluded that:

$\dagger$ Director, Air Pollution Prevention and Control Division, National Risk Management Research Laboratory, Office of Research and Development, U.S. Environmental Protection Agency. A shorter article based on this full length article was previously published in Chemical Engineering Progress. Frank Princiotta, Mitigating Global Climate Change Through Power-Generation Technology, ChemiCal Engineering Progress, Nov. 2007, at 24. 
- "Warming of the climate system is unequivocal, as is now evident from observations of increases in global average air and ocean temperatures, widespread melting of snow and ice and rising global average sea level."

- "Most of the observed increase in global average temperatures since the mid-20th century is very likely due to the observed increase in anthropogenic [greenhouse gas] concentrations."

- "The combined radiative forcing due to increases in [carbon dioxide]... is very likely to have been unprecedented in more than 10,000 years."

- "The total temperature increase from 1850-1899 to 20012005 is $0.76^{\circ} \mathrm{C}\left[0.57^{\circ} \mathrm{C}\right.$ to $\left.0.95^{\circ} \mathrm{C}\right] .{ }^{\prime 4}$

- Depending on the assumed greenhouse gas emission trajectory, warming in 2095, relative to pre-industrial levels, is projected to be 1.6 to $6.4^{\circ} \mathrm{C} .^{5}$

Given these findings, this paper will examine the critical energy sector with the aim of evaluating the ability of technologies to moderate projected warming. The author will begin with a discussion of the factors that lead to increasing emissions of $\mathrm{CO}_{2}{ }^{6}$ the critical greenhouse gas, and the anticipated importance of key countries. Next, $\mathrm{CO}_{2}$ emissions will be projected into the future for key sectors. The author will then summarize the state of the art of technologies and research and development priorities for the key power generation sector. Finally, the adequacy of research, development, demonstration $(\mathrm{R}, \mathrm{D}, \& \mathrm{D})$ and deployment will be discussed.

1. Intergovernmental Panel on Climate Change, Climate Change 2007: SYNTHESIS REPORT 72 (A. Allali et al. eds., 2007) [hereinafter SYNTHESIS REPORT], available at http://www.ipcc.ch/pdf/assessment-report/ar4/syr/ar4_syr.pdf.

2. Id. at 39 .

3. Id. at 37-38.

4. Intergovernmental Panel on Climate Change, Summary for Policymakers, in Climate Change 2007: The Physical Science Basis. Contribution of Working GROUP I TO THE FOURTH ASSESSMENT REPORT OF THE INTERGOVERNMENTAL PANEL ON Climate Change 5 (S. Solomon et al. eds., 2007) [hereinafter Summary FOR POLICYMAKERS], available at http://www.ipcc.ch/pdf/assessment-report/ar4/wg1/ar4-wg1spm.pdf.

5. Id. at 13 .

6. Note that in this paper, all $\mathrm{CO}_{2}$ concentrations will be in parts per million (ppm) and all warming will be realized or transient warming, unless specifically identified, as opposed to equilibrium, also known as eventual warming. 
Although the scope of this paper is limited to a consideration of power generation technologies that can play a significant role in reducing $\mathrm{CO}_{2}$ emissions, it is important to note that availability of such technologies will be necessary but not sufficient to constrain emissions. Since many of these technologies have higher costs and/or greater operational uncertainties than currently available carbon intensive technologies, robust policies will need to be in place to encourage their utilization.

\section{FACTORS THAT DRIVE EMISSIONS OF $\mathrm{CO}_{2}$}

The World Resources Institute has examined the factors that have driven $\mathrm{CO}_{2}$ emissions for key countries in the 1992 to 2002 time period. ${ }^{7}$ The factors considered are: Gross Domestic Product (GDP), growth per capita, population growth, carbon intensity growth per unit of energy (more coal in the mix increases this factor), and the growth of energy usage per unit of GDP. ${ }^{8}$ The sum of these factors approximates the annual $\mathrm{CO}_{2}$ growth rate. ${ }^{9}$ The author has used the Institute's data to generate Figure 1, which shows how these factors have influenced the annual growth rate of $\mathrm{CO}_{2}$ for selected countries during this ten-year period. As can be seen for the world, despite decreases in the energy use per unit of GDP, the $\mathrm{CO}_{2}$ growth rate has been about $1.4 \%$ per year. The rate for the United States also has been about $1.4 \%$, but the growth rate for China and India has been about $4 \%$ per year, driven by economic growth, and for India, population growth as well. Note that in the absence of significant decreases in energy use per unit of economic output, $\mathrm{CO}_{2}$ emission growth rates would have been substantially greater.

7. World Resources Institute, Climate Analysis Indicators Tool (CAIT) Version 5.0 (2008), http://cait.wri.org (last visited Mar. 24, 2008).

8. World Resources Institute, Climate Analysis Indicators Tool (CAIT) Version 5.0: Introduction (2008), http://cait.wri.org/cait.php?page=intro\#indicators (last visited Mar. 24, 2008).

9. See The Sustainable Scale Project, The IPAT Equation, http://www.sustainablescale.org/ ConceptualFramework/UnderstandingScale/MeasuringScale/TheIPATEquation.aspx (last visited Mar. 24, 2008). 
Figure 1. Factors driving atmospheric concentrations of $\mathrm{CO}_{2}$ for selected countries.

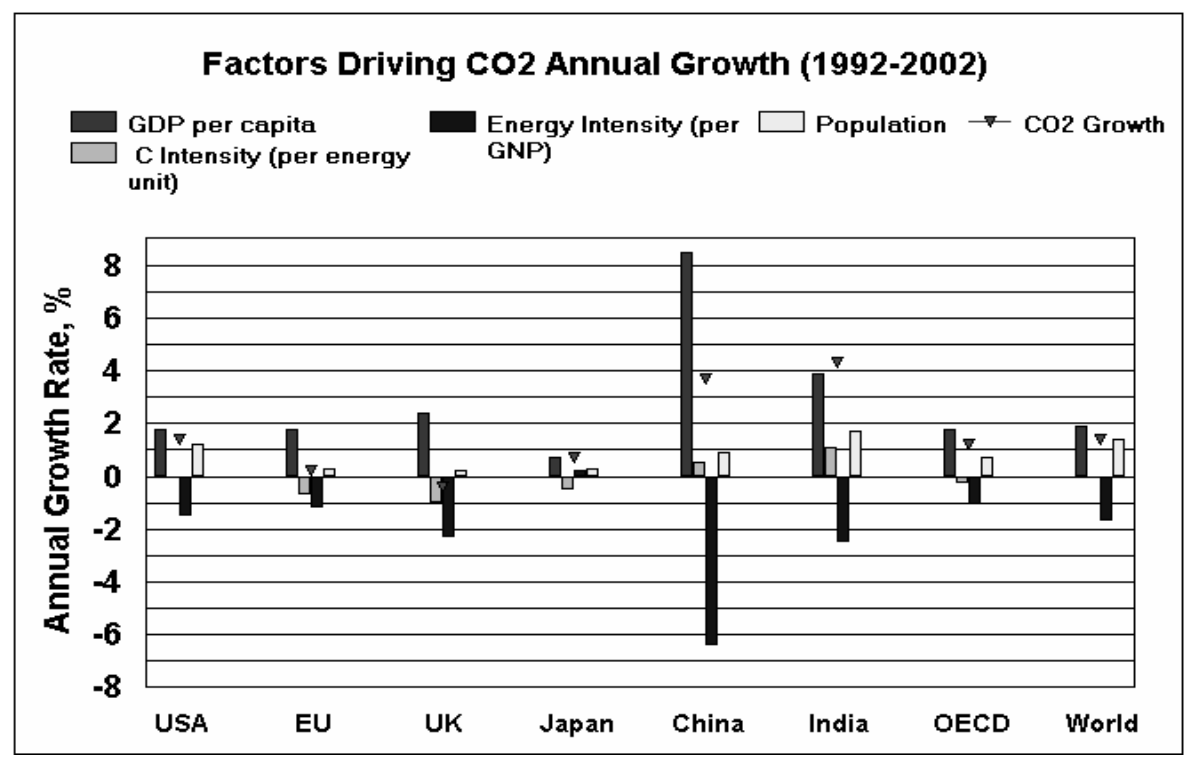

However, a recent analysis by Raupach concluded that in the period 2000 to 2004, worldwide emissions of $\mathrm{CO}_{2}$ have increased more rapidly than in previous years and more rapidly than predicted, at an annual growth rate of $3.2 \%{ }^{10}$ This is more than twice the growth rate of the 1992 to 2002 period. Rapidly developing economies in China and other Asian countries are particularly significant in this recent and troubling trend. "China is currently constructing the equivalent of two 500-megawatt, coal-fired power plants per week and a capacity comparable to the entire United Kingdom power grid each year."11 Figure 2 summarizes these global emission trends, including the recent 2000 to 2004 data.

10. Michael R. Raupach Et al., Global AND Regional Drivers of ACCELERAting $\mathrm{CO}_{2}$ Emissions 2 (William Clark ed., 2007), available at http://www.pnas.org/cgi/reprint/0700609104v1.

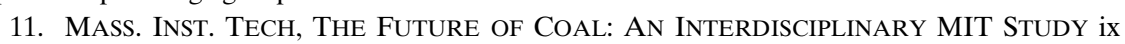
(2007), available at http://web.mit.edu/coal/The_Future_of_Coal.pdf. 
Figure 2. Most Recent $\mathrm{CO}_{2}$ Emission Data by Countries and Sectors. (Note the following regional designations: FSU=republics of the former Soviet Union, D1=15 other developed nations, including Australia, Canada, S. Korea and Taiwan, D2=102 actively developing countries, from Albania to Zimbabwe and D3=52 least developed countries, from Afghanistan to Zambia.)

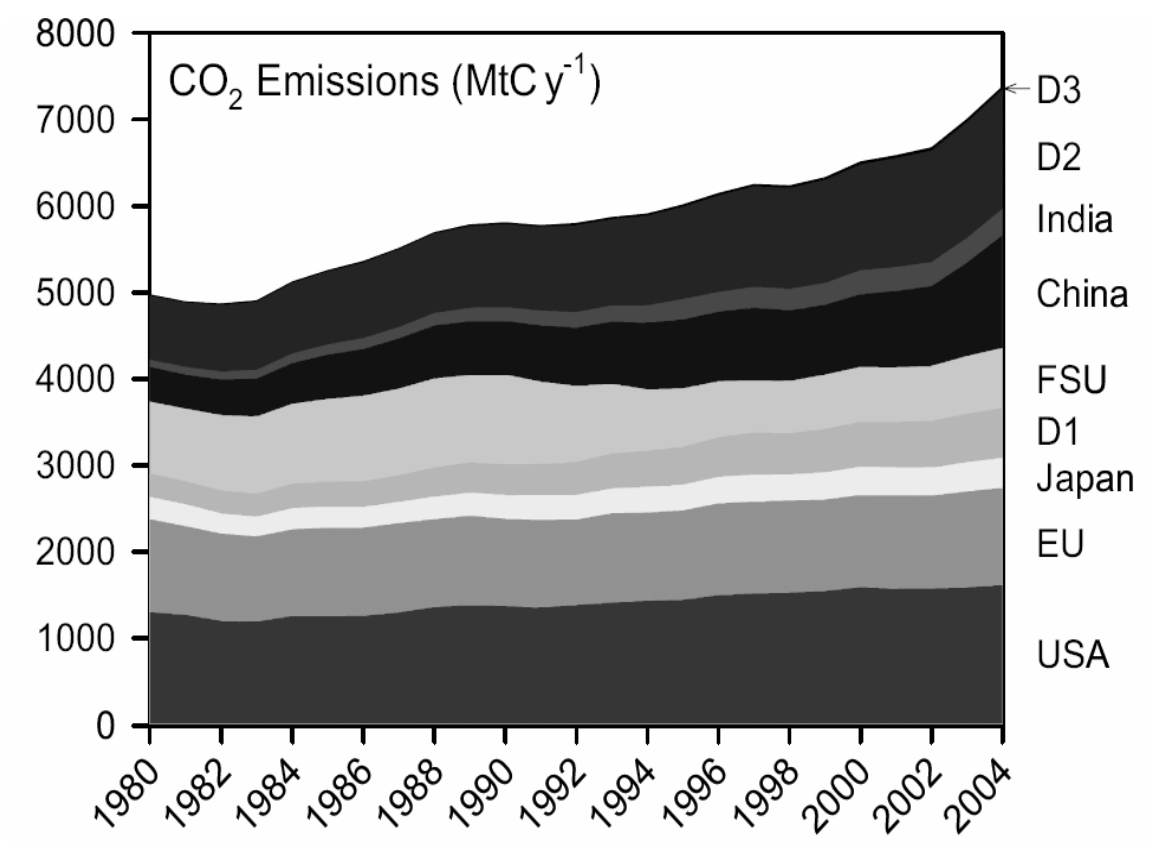

III. WHAT LEVELS OF WARMING ARE PROJECTED, AND WHAT ARE THE UNCERTAINTIES?

A credible base case, or business as usual scenario, must be established if we are to estimate with any confidence warming between now and the year 2100 . IPCC, ${ }^{12}$ the International Energy Agency (IEA), ${ }^{13}$ and Hawksworth ${ }^{14}$ have all postulated such scenarios that allow such estimates. The IEA base scenario was selected as the

12. SUMmARY FOR POLICYMAKeRs, supra note 4, at 13.

13. See, e.g., Int'l Energy Agency, Energy Technology Perspectives 200663 (2006).

14. JOHN HAWKSWORTH, THE WORLD IN 2050: IMPLICATIONS OF GLOBAL GROWTH FOR CARbon Emissions AND Climate Change POlicy 21-22 (2006), available at http://www.pwc.com/extweb/pwcpublications.nsf/docid/DFB54C8AAD6742DB852571F5006DD 532/\$file/world2050carbon.pdf. 
basis for this analysis, since it is consistent with current driving forces and does not assume major technology changes over time. ${ }^{15}$ Since the IEA scenario was limited to estimates through 2050, the author extended it to 2100 by assuming reduced emission growth rates between 2050 and 2100. Thus, the base case scenario assumes the following $\mathrm{CO}_{2}$ growth rates in the specified time intervals: 2000 to $2030,1.6 \% ; 2030$ to $2050,2.2 \% ;^{16} 2050$ to $2075,1.2 \%$; and 2075 to $2100,0.7 \%$. Note that the reduced 2050 to 2100 growth rate assumption was based on projected declines in population growth rates, but relatively stable GDP, carbon intensity, and energy intensity growth rates.

Figures 3 and 4 present model-generated graphics of both $\mathrm{CO}_{2}$ concentrations and warming from pre-industrial times projected to 2100 assuming this emission scenario. The MAGICC (version 4.1) model was used to generate these graphics. ${ }^{17}$ An earlier version of this PC-based model was used by the IPCC in its Third Assessment Report (TAR) to evaluate the impact of various emission scenarios. ${ }^{18}$ MAGICC is a set of coupled gas-cycle, climate, and ice-melt models that allows the determination of the global-mean temperature resulting from user-specified emissions scenarios, ${ }^{19}$ which the author generated. Note that in both figures, the uncertainty range is included. As can be seen, warming uncertainties are much higher than the uncertainties for concentration projections.

Also note, warming is projected to continue after 2100. When one accounts for the continued warming projected into the next century, the equilibrium or eventual warming is projected to range from 3.0 to $8.1^{\circ} \mathrm{C}$, with the best guess at $4.8^{\circ} \mathrm{C}$ above 1990 levels. This projection assumes an ultimate steady atmospheric $\mathrm{CO}_{2}$ concentration of $1000 \mathrm{ppm}$.

The main uncertainty factor for warming projections is the extent to which the atmosphere is sensitive to a doubling of $\mathrm{CO}_{2}$ concentration, i.e., how much does the global equilibrium

15. See InT'L ENERGy AGENCY, supra note 13, at 25.

16. See id. at 62-63. The growth rates assumed up to 2050 were derived by computing growth rates based on the 2003, 2030, and $2050 \mathrm{CO}_{2}$ emissions assumed for the IEA baseline scenario. Figure 2.1, Id. at 46.

17. F.T. Princiotta, Magicc/Sciengen (2004), http://www.cgd.ucar.edu/cas/wigley/magicc/.

18. See Intergovernmental Panel on Client Change, Climate Change 2001: The SCIENTIFIC BASIS 554 (J. Houghton et al. eds., 2001), available at http://www.ipcc.ch/ipccreports/tar/wg1/index.htm.

19. Princiotta, supra note 17. 
temperature change with such a doubling..$^{20}$ IPCC, Wigley, and others state that this is quite uncertain, and their estimates range from $1.5^{\circ} \mathrm{C}$ to $4.5^{\circ} \mathrm{C} .{ }^{21}$

Figure 3. Projected $\mathrm{CO}_{2}$ concentrations for Base Case

\section{Carbon Dioxide Concentration (ppmv)} Reference: IEA Modified Base Case

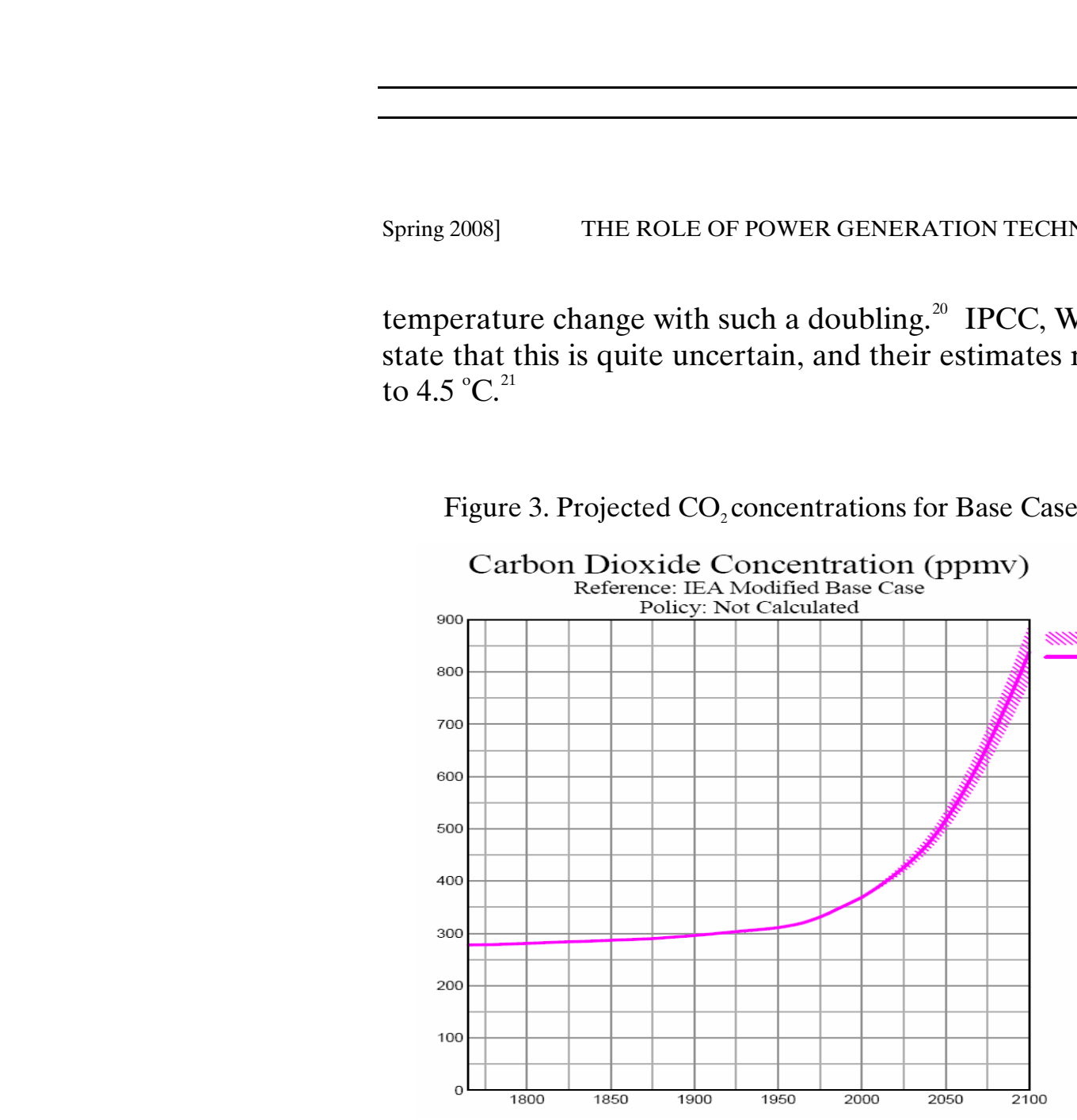

20. See SYNTHESIS REPORT, supra note 1 , at 38.

21. Id.; T. Wigley \& S. Raper, Interpretation of High Projections for Global-Mean Warming, 293 SCIENCE 451, 452 (2001). 
Figure 4. Projected Warming for Base Case

Temperature Change $\left({ }^{\circ} \mathrm{C}\right)$ w.r.t. 1990 Reference: IEA Modified Base Case

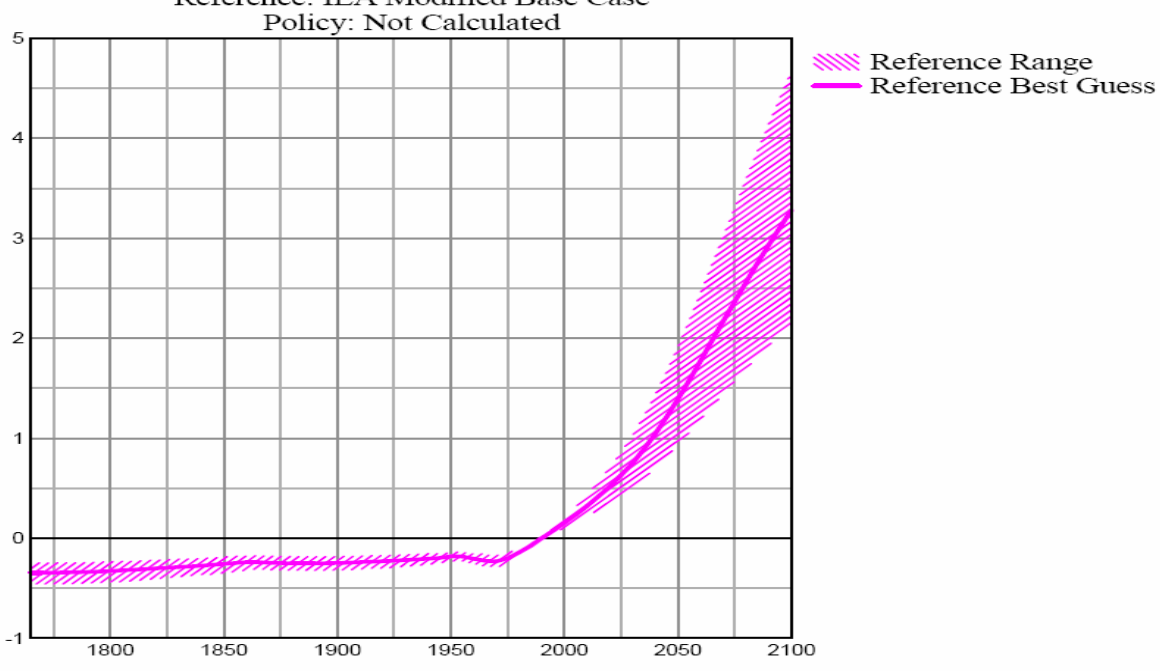

\section{What LeVels of Mitigation Are Achievable?}

Figure 5 presents the recent (April 2007) IPCC analysis relating projected warming from 1990 to 2100 to the following global impacts: fresh water availability, ecosystem damage, food supplies, seawater rise, extreme weather events, and human health impacts. ${ }^{22}$ The author has added projected warming ranges for a credible business as usual case and an aggressive global mitigation case. It is significant that current (2007) warming $\left(0.3^{\circ} \mathrm{C}\right.$ since 1990 and $0.8^{\circ} \mathrm{C}$ since 1750) has already had measurable impacts.

As derived from the MAGICC model shown in Figure 4, base case warming in 2100 (from 1990) is projected to be from 2.2 to $4.7^{\circ} \mathrm{C}$ (with $3.2^{\circ} \mathrm{C}$ as the best guess), yielding potentially severe impacts, especially in the middle and upper end of this uncertainty range. Particularly troublesome impacts include: millions of people under water scarcity stress, wide scale ecosystem extinctions, lower food production in many areas, loss of wetlands, damage and mortality from storms and floods, and increased health impacts from infectious diseases. ${ }^{23}$

22. SYNTHESIS REPORT, supra note 1 , at 48-54.

23. Id. at 31-33. 
It is important to note that when one accounts for current emission trends, the current unavailability of low emitting technologies, and the likelihood of inaction in the near term, limiting warming to $2.0^{\circ} \mathrm{C}$ (range of 1.3 to $2.8^{\circ} \mathrm{C}$ ) is likely the best result achievable, even with a major global mitigation program (e.g., decreasing $\mathrm{CO}_{2}$ emissions $1 \%$ per year starting in 2010). ${ }^{24}$ Figure 6 indicates global impacts will be significant, even assuming such an aggressive mitigation case.

Therefore, for this analysis, emission scenarios were evaluated to see what reduction levels, starting in what year, would limit warming below about $2.0^{\circ} \mathrm{C}$. Figures 6 and 7 depict results of a large number of MAGICC cases, indicating annual emission reductions required to meet this warming goal, along with corresponding $\mathrm{CO}_{2}$ concentration estimates. Note that an annual decrease of $0.00 \%$ means emissions are held constant at the level of the starting year.

24. Princiotta, supra note 17. 
Figure 5. Projected global warming impacts as a function of warming (in ${ }^{\circ} \mathrm{C}$ ) from 1990 to 2100. (Impact starts at beginning of narrative and dotted arrows indicate impacts increase with increasing warming.)

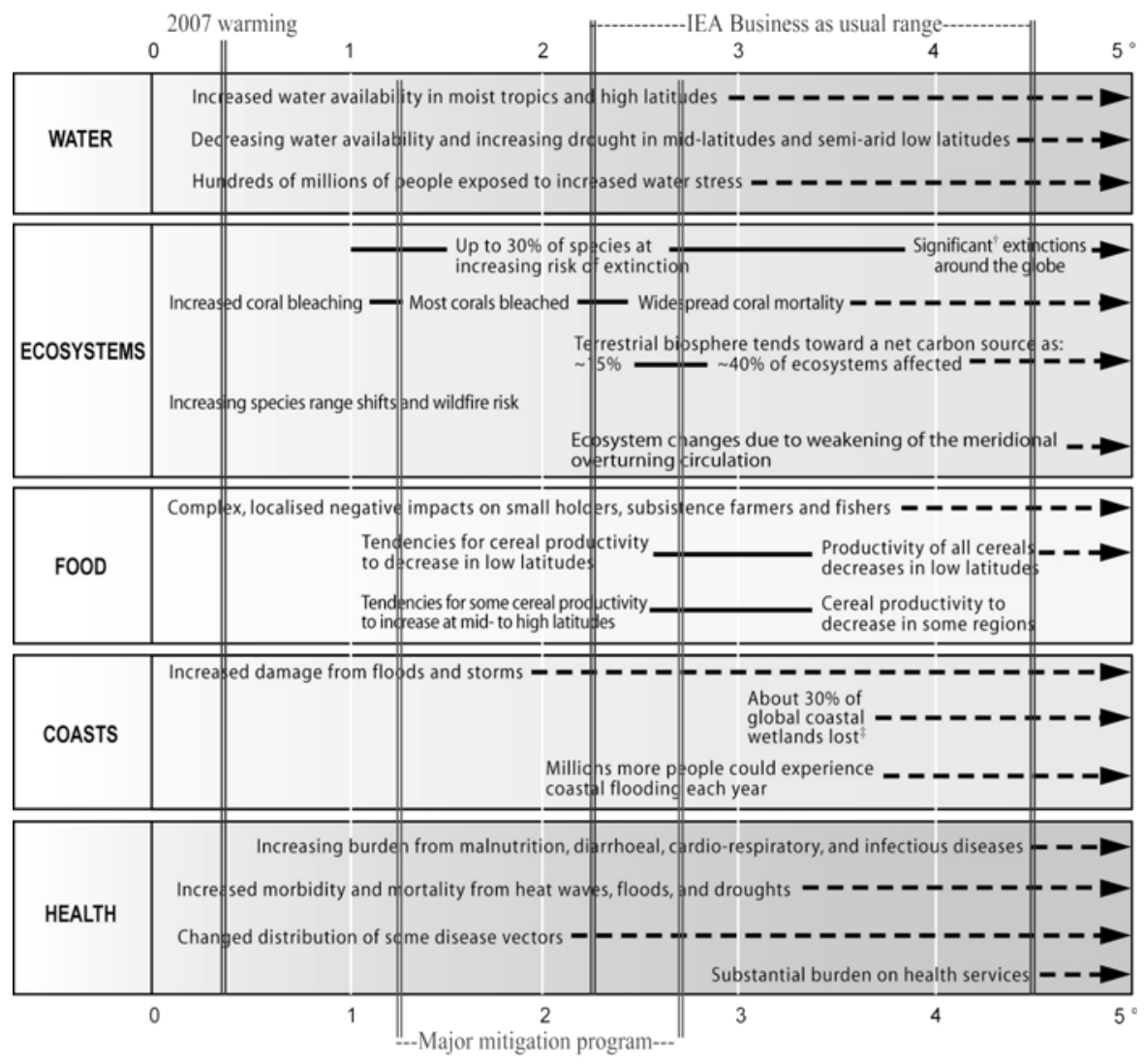


Figure 6. Best guess 2100 warming as function of annual emission decrease rate and year reductions start

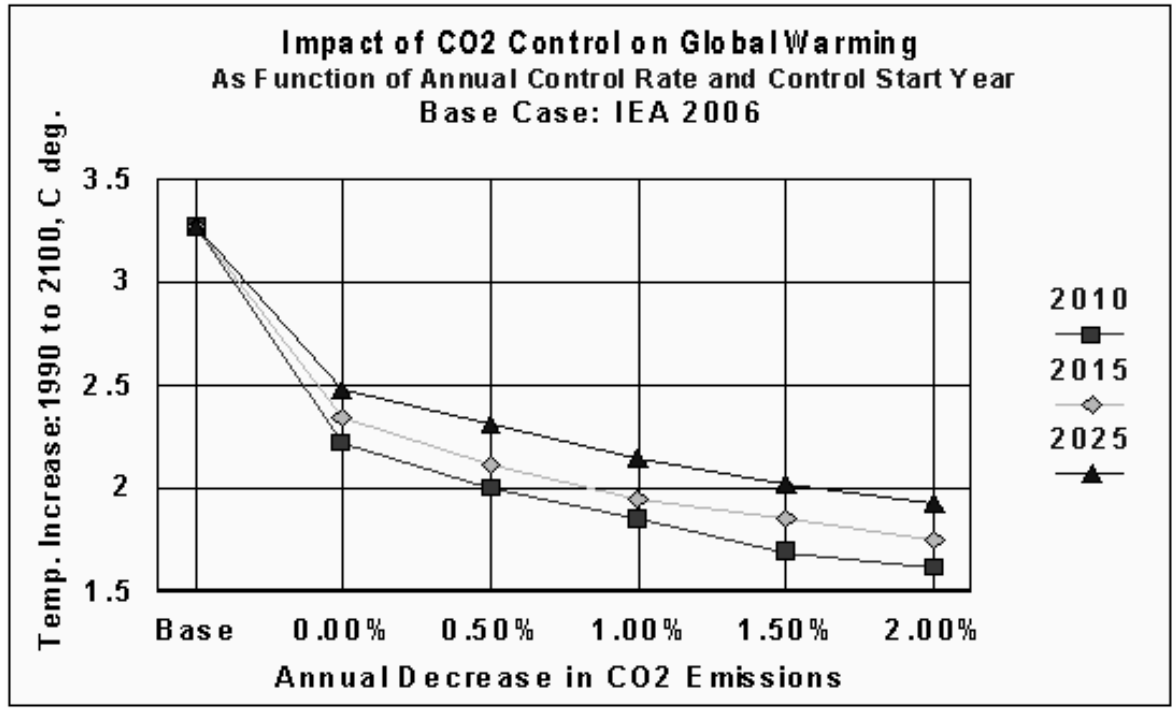

Figure 7. $\mathrm{CO}_{2}$ concentration (ppm) in 2100 as a function of annual emissions decrease rate and year reductions start

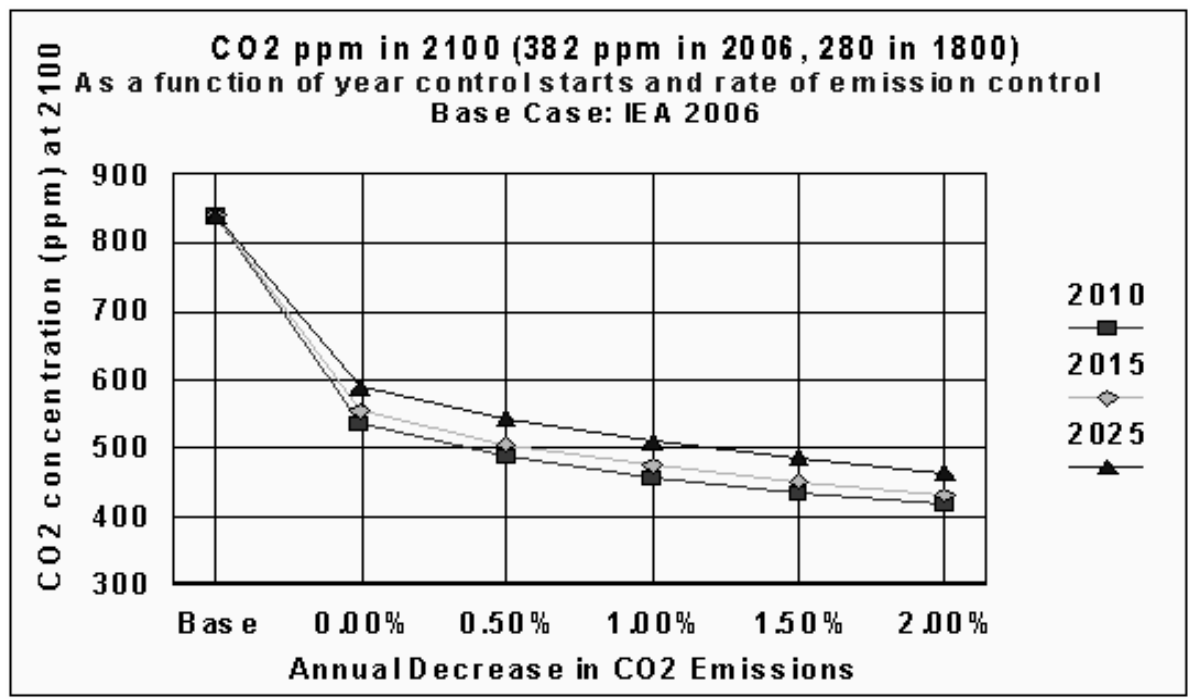

As can be seen in Figures 6 and 7, major annual decreases in emissions will be necessary if a warming target below $2.0^{\circ} \mathrm{C}$ is to be achieved. Note that the earlier this reduction starts, the less the annual reduction rate has to be to meet a given warming target. For 
example, if such a program were to start in 2015, reductions would need to be about $1 \%$ annually to limit warming to about $2.0^{\circ} \mathrm{C}$ above the 1990 level; whereas if such a program were to start in 2025, annual reductions would need to be about $1.8 \% .^{25}$ Again, it must be noted that there is a large range of uncertainty in the resulting temperature for a given maximum $\mathrm{CO}_{2}$ concentration. Figure 8 illustrates this uncertainty by displaying the range of projected warming, from 1990, for a particular emission scenario, i.e., an annual decrease of $1 \%$, starting in 2010, projected to constrain concentrations to the 440 to $480 \mathrm{ppm}$ range. Note that the high end of this range is higher than the low end of the business-as-usual case. ${ }^{26}$ This highlights the magnitude of the uncertainties in our current models, of which MAGICC is representative.

Figure 8. Projected warming range for a $1 \%$ annual decrease in $\mathrm{CO}_{2}$ emissions started in 2010

Temperature Change $\left({ }^{\circ} \mathrm{C}\right)$ w.r.t. 1990

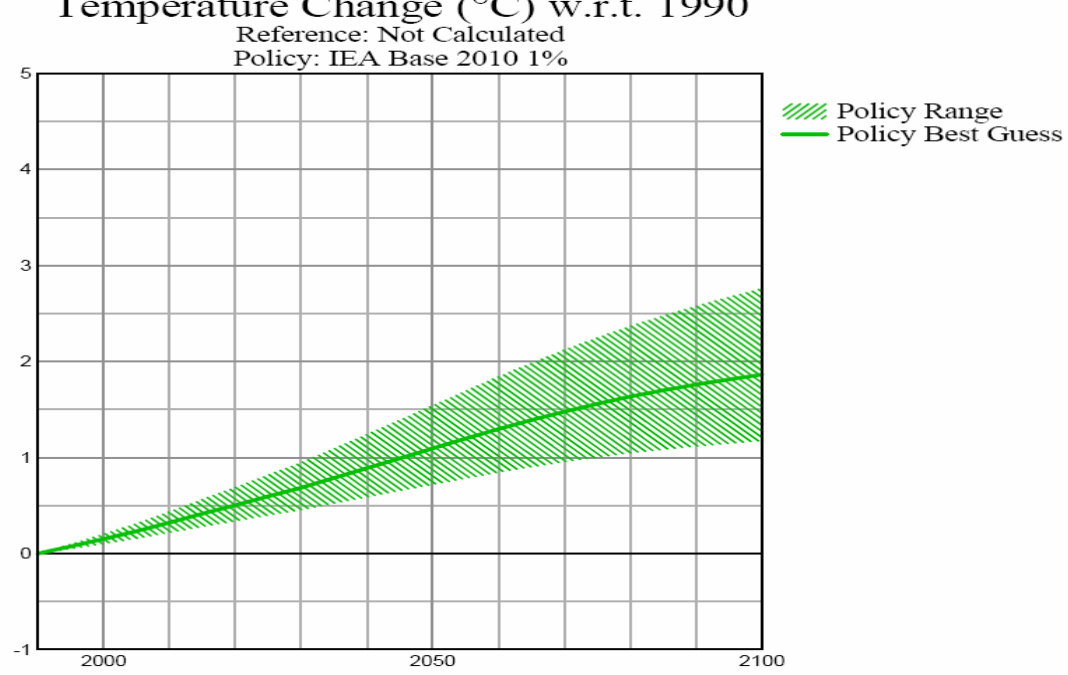

Figure 9 illustrates the major challenge such reductions represent, relative to our base case emission trends. The base case emission trajectory is compared to a mitigation scenario where emissions are decreasing at a rate of 1\% per year starting in 2010. Such a policy would limit atmospheric $\mathrm{CO}_{2}$ concentration to $460 \mathrm{ppm}$ and warming to $1.9^{\circ} \mathrm{C}$ above 1990 levels.

25. See supra Figure 6.

26. See supra Figure 4. 
Figure 9. Base case and policy scenario to limit warming in 2100 to less than $2^{\circ} \mathrm{C}$; units: Gigatons (Gt) Carbon (Note: $3.67 \mathrm{Gt} \mathrm{CO}_{2}$ per Gt C)

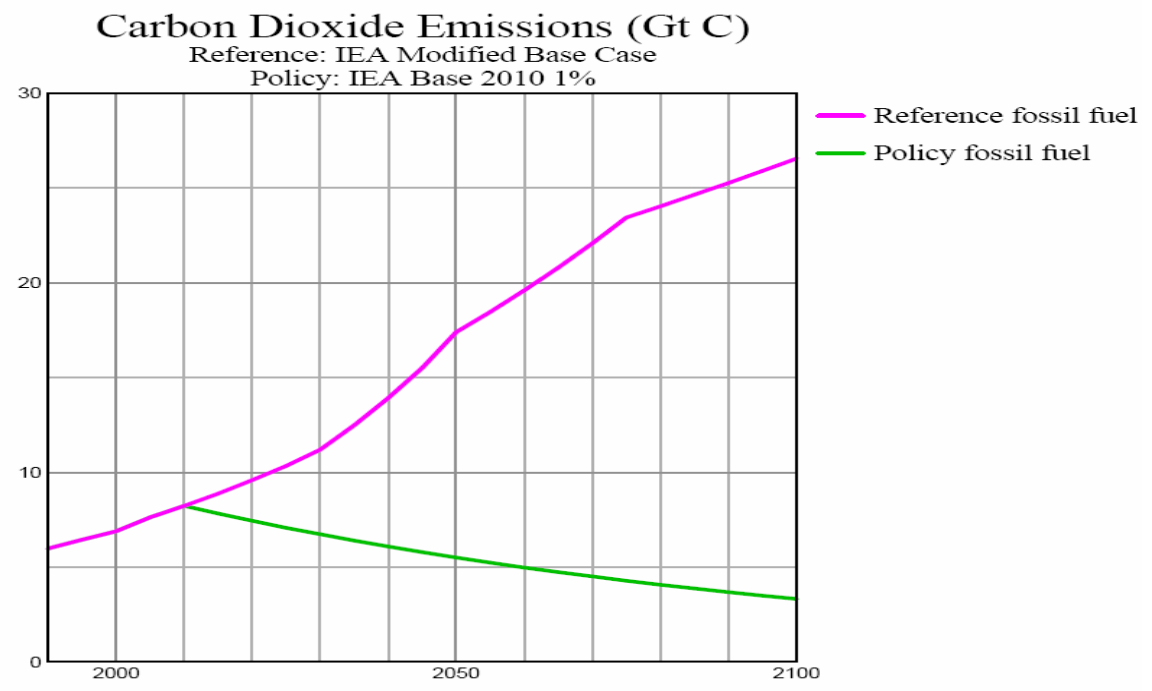

Note that the area between the curves represents the amount of carbon avoidance needed to achieve the target temperature versus the base case: over one trillion tons of carbon or over 3.7 trillion tons of $\mathrm{CO}_{2}$ over the 90-year period. This represents what can only be described as a monumental political, social, and technological challenge.

\section{THE Mitigation CHALlEngE: WHICH SECTORS ARE MOST IMPORTANT?}

In order to identify the most productive mitigation strategies, it is necessary to understand the current and projected sources of $\mathrm{CO}_{2}$ and the other greenhouse gases. The author has derived the information in Figure 10 from IEA. ${ }^{27}$ The upper graphic projects world $\mathrm{CO}_{2}$ emissions by sector. It suggests that power generation and transportation sources are the fastest growing sectors and will be the key to any successful mitigation strategy. There is historical evidence that as a country develops economically, it uses greater quantities of electrical power and experiences a sharp growth in the number and 
use of motor vehicles and other transportation sources. ${ }^{28}$ China and India, with a cumulative population of over 2.4 billion, are projected to continue their rapid economic expansion with commensurate pressure on the power generation and transportation sectors. ${ }^{29}$

Figure 10. Base case, ACT MAP Control Scenario and $\mathrm{CO}_{2}$ Emissions Avoided. $^{30}$

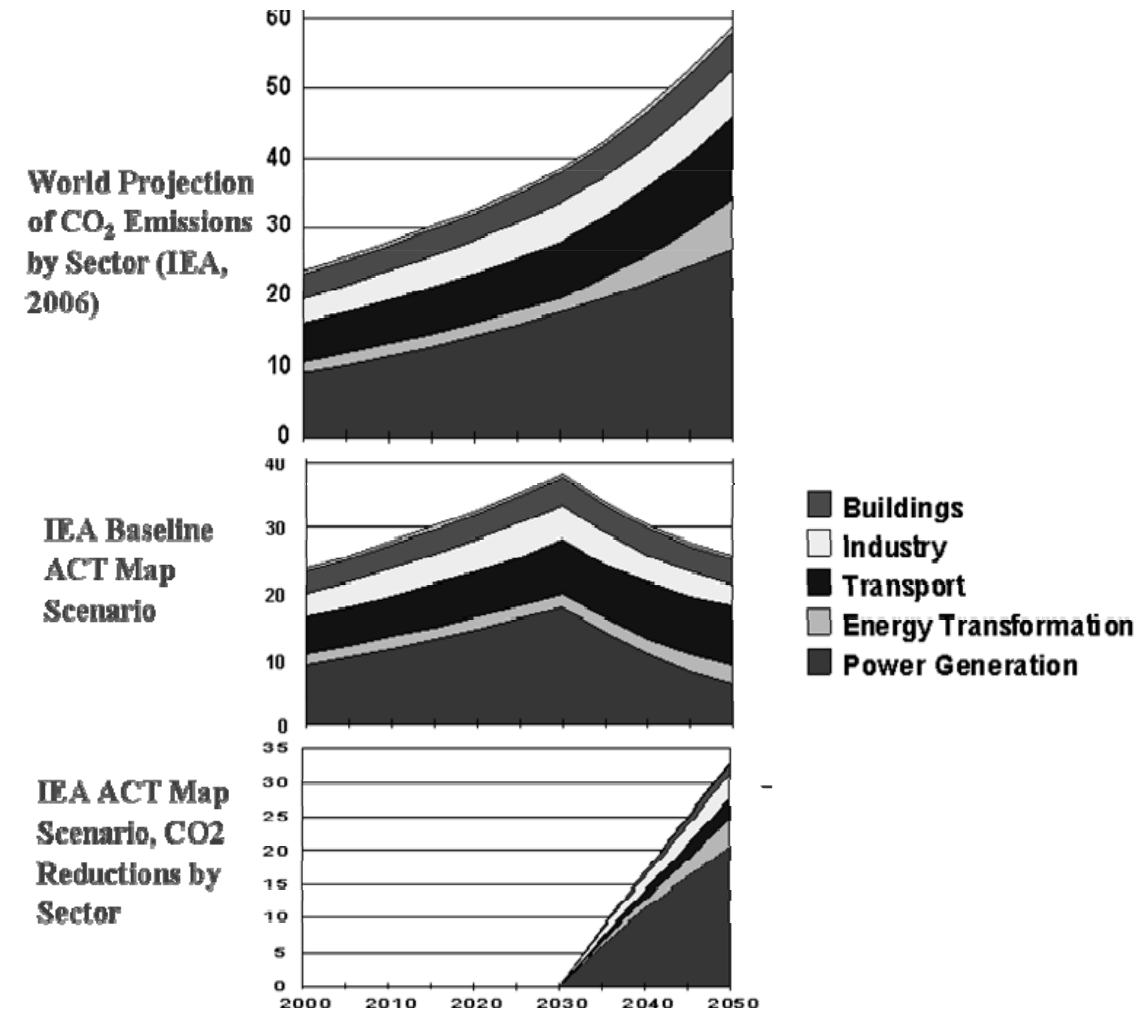

VI. The Mitigation Challenge: What Role CAn ENERgy TECHNOLOGy Play, AND What ARE THE Options?

At the request of G-8 Leaders \& Energy Ministers, in 2005, in order to understand the potential of various energy technologies to avoid $\mathrm{CO}_{2}$ emissions, IEA evaluated what it called Accelerated

28. Fulvio Beato \& Francesco Chiarello, Population, Environment and Economic Growth: A Sociological Perspective, THEOMAI, PRIMER SEMESTRE, NUMERO 001, UNIVERSIDAD NACIONAL DE QUILMES 1, 7-8 (2000).

29. INT'L ENERGY AGENCY, supra note 13, at 451-52.

30. See id. at 45-47. 
Technology (ACT) scenarios. ${ }^{31}$ Of these, the ACT Map scenario is the most optimistic, assuming an aggressive and successful R,D,\&D program to develop and improve technologies and a comprehensive technology demonstration and deployment program. $^{32}$ It also assumes policies in place that would encourage the use of these technologies in an accelerated timeframe. ${ }^{33}$ Such policies include $\mathrm{CO}_{2}$ reduction incentives to encourage low-carbon technologies with costs up to $\$ 25 /$ metric ton $\mathrm{CO}_{2}$ in all countries from 2030 to 2050 . $^{34}$ The incentives could take the form of "regulation, pricing, tax breaks, voluntary program[]s, subsidies, or trading schemes." 35

The middle graphic of Figure 10 projects $\mathrm{CO}_{2}$ emissions by sector, according to the ACT Map scenario, based on the IEA's assumption that major technology implementation starts in 2030. The bottom graphic depicts the $\mathrm{CO}_{2}$ savings projected by sector, using the ACT Map scenario. Most of the savings relate to the power generation sector, which includes both production and end use savings. Note that savings attributed to the transportation sector include the savings associated with transforming less coal, petroleum, and natural gas to liquid fuels and their associated $\mathrm{CO}_{2}$ emissions. ${ }^{36}$ This IEA scenario is projected to result in the mitigation of $32.5 \mathrm{Gt}$ of $\mathrm{CO}_{2}$ in $2050 .^{37}$ As will be discussed subsequently, this level of mitigation would be impossible without the use of improved, and in some cases breakthrough, energy technologies. Such technologies are necessary for both energy production, such as power generation, and to enhance end use efficiency, such as with lower emission vehicles.

It is important to note that for the IEA Map scenario extended to 2100, MAGICC calculations indicate best-guess $\mathrm{CO}_{2}$ concentrations of $500 \mathrm{ppm}$ in 2100 and corresponding warming of $2.1^{\circ} \mathrm{C}$ relative to $1990 .^{38}$ This is despite the IEA assumption of an aggressive $\mathrm{R}, \mathrm{D}, \& \mathrm{D}$ and deployment program and the author optimistically assuming further major ( $2 \%$ per year) emission reductions for 50 years beyond the IEA timeframe of 2050. This suggests that even a major global mitigation program, based on

31. Id. at 25 .

32. See id. at 42 .

33. See id. at $41-42$.

34. Id. at 41 .

35. Id.

36. See id. at 47 n.5.

37. Id. fig. 2.2 .

38. See supra Figs. $6 \& 7$. 
successful development and deployment of several new technologies, will still allow substantial global warming by 2100 .

Let us now focus on the critical power sector and examine the technology options available, their current state of the art, and the required $\mathrm{R}, \mathrm{D}, \& \mathrm{D}$ for them to meet their potential to avoid $\mathrm{CO}_{2}$ emissions.

\section{POWER GENERATION SECTOR}

Of all sectors, the power generation sector, which is projected to grow at an annual rate of $2 \%,{ }^{39}$ has the greatest potential to reduce $\mathrm{CO}_{2}$ emissions in the coming decades. However, it should be noted that there are major capacity expansions underway for coal-fired power generation in China, India, and other countries. ${ }^{40}$ Since such plants have no $\mathrm{CO}_{2}$ mitigation technology planned and can have lifetimes up to 50 years, the sooner technology is ready for implementation and mandated, the sooner new plants can incorporate such technology and control emissions. Current retrofit technology is theoretically available, but will likely be substantially more expensive per unit of power generated than would be the case for new plants with $\mathrm{CO}_{2}$ capture built in or for advanced $\mathrm{CO}_{2}$ removal retrofit technology now in the early development stages. ${ }^{41}$

Major reductions can result from lower emissions on the generation side and lower usage, via enhanced end use efficiency, on the user side. Table 1 presents a summary of major generation options that offer significant opportunities for $\mathrm{CO}_{2}$ mitigation. ${ }^{42}$ They are presented in the order of highest potential for $\mathrm{CO}_{2}$ mitigation consistent with the IEA ACT Map scenario. ${ }^{43}$ Included in this and the subsequent tables are the IEA projected $\mathrm{CO}_{2}$ savings for each technology in Gigatons of $\mathrm{CO}_{2}$ in $2050 .{ }^{44}$ To put these numbers in perspective, to achieve the mitigation depicted in Figure 9, total required savings in 2050 is about $40 \mathrm{Gt} \mathrm{CO}_{2}(10.9 \mathrm{Gt} \mathrm{C})$, and for the less aggressive IEA Map scenario, $32 \mathrm{Gt}$ of mitigation would be accomplished. $^{45}$

39. Author's conclusion based on attendance at Int'l Conference on Power Engineering (ICOPE) meeting in Hangzhou, China, October 23-27, 2007.

40. Id.

41. See InT'L ENERgy AgENCY, supra note 13, at 182-83, 198.

42. See infra Table 1.

43. See id.

44. INT'L ENERGY AGENCY, supra note 13, at 116, 124, 133.

45. Id. at 51 . 
Key generation technologies include nuclear power, natural gas/combined cycle, and three coal combustion technologies (integrated gasification combined cycle (IGCC), pulverized coal/oxygen combustion, and conventional pulverized coal), all with integrated $\mathrm{CO}_{2}$ capture and underground storage. ${ }^{46}$ The three coal capture technologies are quite important; the IEA scenario projects each of the three to avoid $1.3 \mathrm{Gt}$ of $\mathrm{CO}_{2}$ in $2050 .^{47}$ Figure 11 illustrates the major components of each technology. ${ }^{48}$ IGCC technology is the primary focus of the U.S. R,D,\&D program, but it requires complex chemical processing and pure oxygen for the gasification process, and it cannot be readily retrofitted to existing plants. $^{49}$ Oxy-combustion systems also require pure oxygen for combustion but are less complex and have the potential for retrofitting existing plants. ${ }^{50} \mathrm{CO}_{2}$ removal via scrubbing, adsorption, or membrane separation is conceptually simple and is inherently retrofitable, but it is at an early development stage; commercial amine scrubbers use large quantities of energy for sorbent regeneration and are expensive. ${ }^{51}$ MIT recently completed an in-depth study of coal in a carbon constrained world and concluded that " $\mathrm{CO}_{2}$ capture and sequestration is the critical enabling technology that would reduce $\mathrm{CO}_{2}$ emissions significantly while also allowing coal to meet the world's pressing energy needs." ${ }^{52}$ The study concluded that current research funding is inadequate and "what is needed is to demonstrate an integrated system of capture, transportation and storage of $\mathrm{CO}_{2}$, at scale." 53

With the exception of wind power, renewable technologies (italicized text in Table 1) are not projected to have major mitigation impacts in the 2050 timeframe. ${ }^{54}$ In the case of solar generation, the technology is projected to be prohibitively expensive unless there is a major research breakthrough. ${ }^{55}$ For biomass, major utilization is projected to be limited by its dispersed nature, its low energy density,

\footnotetext{
46. See id. at 114-15, 132-33.

47. Id. at 116 .

48. Generated by author from similar diagrams.

49. See INT'L ENERGY AGENCY, supra note 13, at 190-92, 202-03.

50. Id. at 201-02.

51. Id. at 200-01.

52. MASS. INST. TECH, supra note 11 , at $\mathrm{x}$.

53. Id. at xi.

54. INT'L ENERGY AGENCY, supra note 13, at 206-46.

55. Id. at 224-28.
} 
and competition for the limited resource in the transportation sector. ${ }^{56}$

The author rates $\mathrm{R}, \mathrm{D}, \& \mathrm{D}$ needs in the power generation sector as critical, especially in the area of $\mathrm{CO}_{2}$ capture and storage (CCS) and for the next generation of nuclear power plants. All three capture technologies described above warrant aggressive $R, D, \& D$ programs. The author concurs with $\mathrm{MIT}^{57}$ that there are too many uncertainties with regard to IGCC to limit $\mathrm{R}, \mathrm{D}, \& \mathrm{D}$ focus to that technology alone. Therefore, much more emphasis should be placed on pulverized coal/oxygen (oxy-fuel) combustion and high efficiency pulverized coal with $\mathrm{CO}_{2}$ flue gas capture technology. Underground sequestration will be needed for each of these technologies and is in an early developmental stage, with extraordinary potential. However, there are a host of questions that can be resolved only through a major program with a particular focus on demonstrations for the key geological formations, most applicable to the greatest potential capacity. MIT estimates that three full scale CCS projects in the United States, and ten worldwide, are needed to cover the range of likely accessible geologies for large scale storage. ${ }^{58}$

For advanced nuclear power, the technology is quite promising and could start making a major impact by $2030 .{ }^{59}$ However, the technology needs a number of successful demonstrations to allow for resolution of remaining technical problems and to instill confidence in the utility industry that the technology is affordable and reliable, and confidence in the public that the technology is safe.

Figure 12 summarizes the IEA projection for the impact of key technologies in avoiding $\mathrm{CO}_{2}$ emissions in the power generation sector in $2050 .^{60}$ As can be seen, assuming aggressive $R, D, \& D$ and incentive programs, end use efficiency improvements, carbon capture and sequestration, and nuclear power are projected to play important roles in that timeframe.

56. Id. at 209-14.

57. MASS. INST. TECH., supra note 11, at xiii.

58. Id. at 53-54.

59. See INT'L ENERGy AGENCY, supra note 13, at 233-46.

60. Id. at 51-52. 


\begin{tabular}{|c|c|c|c|c|}
\hline Technology & Current State of the Art & $\frac{2050}{\text { Impact }}$ & Issues & R,D \&D Needs \\
\hline $\begin{array}{l}\text { Nuclear Power-next } \\
\text { generation }\end{array}$ & \begin{tabular}{|l|} 
Developmental, Generation III+ \\
and IV: e.g. Pebble Bed Modular \\
Reactor and Supercritical Water \\
Cooled Reactor
\end{tabular} & 1.9 & $\begin{array}{l}\text { Deployment targeted by } 2030 \text { with a } \\
\text { focus on lower cost, minimal waste, } \\
\text { enhanced safety and resistance to } \\
\text { proliferation }\end{array}$ & $\begin{array}{l}\text { High, Demonstrations of key technologies } \\
\text { with complimentary research on } \\
\text { important issues }\end{array}$ \\
\hline $\begin{array}{l}\text { Nuclear Power-current } \\
\text { generation }\end{array}$ & $\begin{array}{l}\text { Commercial, Pressurized W ater } \\
\text { Reactors and Boiling Water } \\
\text { Reactors (G eneration III) }\end{array}$ & 1.8 & $\begin{array}{l}\text { Plant siting, high capital costs, le velized } \\
\text { cost } 10 \text { to } 40 \% \text { higher than coal or gas } \\
\text { plants, potential U shortages, safety, } \\
\text { waste disposal and proliferation }\end{array}$ & Medium, Waste disposal research \\
\hline $\begin{array}{l}\text { Natural Gas Combined } \\
\text { Cycle }\end{array}$ & Commercial, $60 \%$ efficiency & 1.6 & \begin{tabular}{|l} 
Limited by natural gas availability, \\
which is major constraint; high \\
efficiency \& low capital costs
\end{tabular} & $\begin{array}{l}\text { Medium, higher efficiencies with new } \\
\text { materials desirable }\end{array}$ \\
\hline Wind Power (renewable) & Commercial & 1.3 & $\begin{array}{l}\text { Costs very dependent on strength of } \\
\text { wind source, large turbines visually } \\
\text { obtrusive, intermittent power source }\end{array}$ & $\begin{array}{l}\text { Medium, higher efficiencies, on-shore } \\
\text { demonstrations }\end{array}$ \\
\hline $\begin{array}{l}\text { Coal IGCC with CO2 } \\
\text { Capture and Storage }\end{array}$ & $\begin{array}{l}\text { IGCC : early commercialization, } \\
\text { Underground storage (US) : early } \\
\text { development. }\end{array}$ & 1.3 & $\begin{array}{l}\text { IGCC: High capital costs, questionable } \\
\text { for low rank coals, complexity and } \\
\text { potential reliability concerns; US: Cost, } \\
\text { safety, efficacy }\end{array}$ & $\begin{array}{l}\text { High, IGCC: Demos on a variety of coals, } \\
\text { hot gas cleanup research; } U S \text { : major } \\
\text { program with long term demos evaluating } \\
\text { large number of geological formations to } \\
\text { evaluate efficacy, cost and safety }\end{array}$ \\
\hline \begin{tabular}{|l} 
Pulverized Coal/Oxygen \\
combustion with CO2 \\
Capture and Storage
\end{tabular} & Developmental & 1.3 & $\begin{array}{l}\text { Oxygen combustion allows lower cost } \\
\text { CO2 scrubbing, but oxygen production } \\
\text { cost is high; US : Cost, safety and } \\
\text { permanency }\end{array}$ & $\begin{array}{l}\text { High, large pilot followed by full scale } \\
\text { demos needed, low cost } \mathrm{O}_{2} \text { production } \\
\text { needed, US requires major program (see } \\
\text { write-up above) }\end{array}$ \\
\hline $\begin{array}{l}\text { Pulverized Coal with CO2 } \\
\text { Capture and Storage }\end{array}$ & $\begin{array}{l}\text { Underground storage } \\
\text { developmental; CO2 scrubbing } \\
\text { with MEA near commercial but } \\
\text { too expensive }\end{array}$ & 1.3 & $\begin{array}{l}\text { US: Cost, safety and efficacy issues, } \\
\mathrm{CO}_{2} \text { scrubbing energy inten sive: } \\
\text { yielding unacceptable costs }\end{array}$ & $\begin{array}{l}\text { High, US requires major program (see } \\
\text { write-up above); affordable } \mathrm{CO}_{2} \text { removal } \\
\text { technologies need to be developed and } \\
\text { demonstrated }\end{array}$ \\
\hline $\begin{array}{l}\text { Solar-Photovoltaic and } \\
\text { concentrating (renewable) }\end{array}$ & $\begin{array}{l}\text { First generation commercial, but } \\
\text { very high costs }\end{array}$ & 0.5 & $\begin{array}{l}\text { Costs unacceptably high, solar resource } \\
\text { intermittent in many locations }\end{array}$ & $\begin{array}{l}\text { High, breakthrough } R, D \& D \text { needed to } \\
\text { develop \& demo cells with higher } \\
\text { efficiency and lower capital costs }\end{array}$ \\
\hline $\begin{array}{l}\text { Biomass as fuel and co- } \\
\text { fired with coal (renewable) }\end{array}$ & Commercial, steam cycles & 0.5 & $\begin{array}{l}\text { Biomass dispersed source, limited to } \\
20 \% \text { when co-fired with coal }\end{array}$ & $\begin{array}{l}\text { Medium, biomass/IGCC would enhance } \\
\text { efficiency and } \mathrm{CO} 2 \text { benefit; also genetic } \\
\text { engineering to enhance biomass } \\
\text { plantations }\end{array}$ \\
\hline Hydroelectric (renewable) & Commercial & 0.5 & $\begin{array}{l}\text { Capital costs high, potential ecological } \\
\text { disruption, siting challenges }\end{array}$ & $\begin{array}{l}\text { Medium, minimize environmental } \\
\text { footprint }\end{array}$ \\
\hline $\begin{array}{l}\text { More Efficient Coal Fired } \\
\text { Power Plants }\end{array}$ & \begin{tabular}{|l} 
Early commercialization of \\
supercritical and ultra \\
supercritical
\end{tabular} & 0.2 & $\begin{array}{l}\text { Currently maximum efficiency of } 45 \% \text {, } \\
\text { yielding } 36 \% \text { less } \mathrm{CO}_{2} \text { than current flee }\end{array}$ & $\begin{array}{l}\text { High, new affordable materials needed to } \\
\text { enhance efficiency to } 50 \text { to } 55 \%\end{array}$ \\
\hline $\begin{array}{l}\text { Coal IGCC with no CO2 } \\
\text { Capture and Storage }\end{array}$ & IGCC: early commercialization & 0.2 & $\begin{array}{l}\text { IGCC: High capital costs, complexity } \\
\text { and reliability concerns, only modest } \\
\text { CO2 savings without CCS }\end{array}$ & $\begin{array}{l}\text { High, Demos on a variety of coals, hot gas } \\
\text { cleanup research }\end{array}$ \\
\hline
\end{tabular}


Figure 11. Three key technologies capturing $\mathrm{CO}_{2}$ from coal-fired power plants

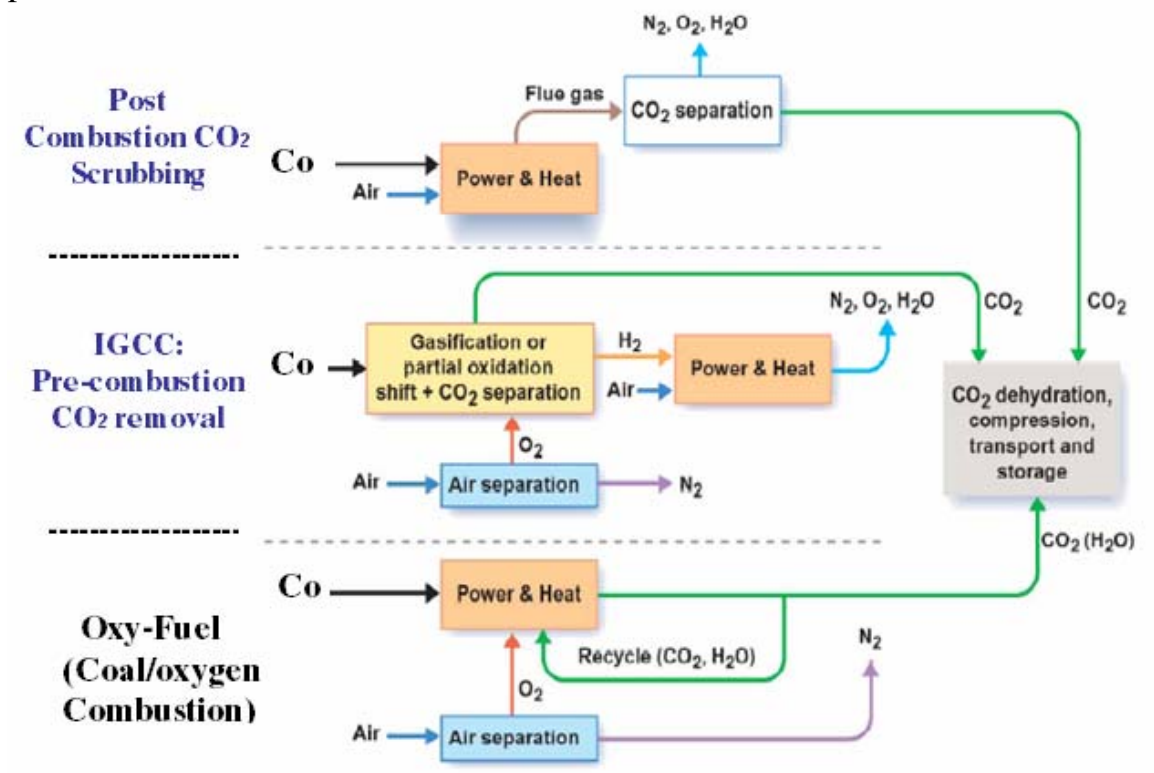

Figure 12. For ACT Map scenario, projected $\mathrm{CO}_{2}$ savings in power generation sector by technology

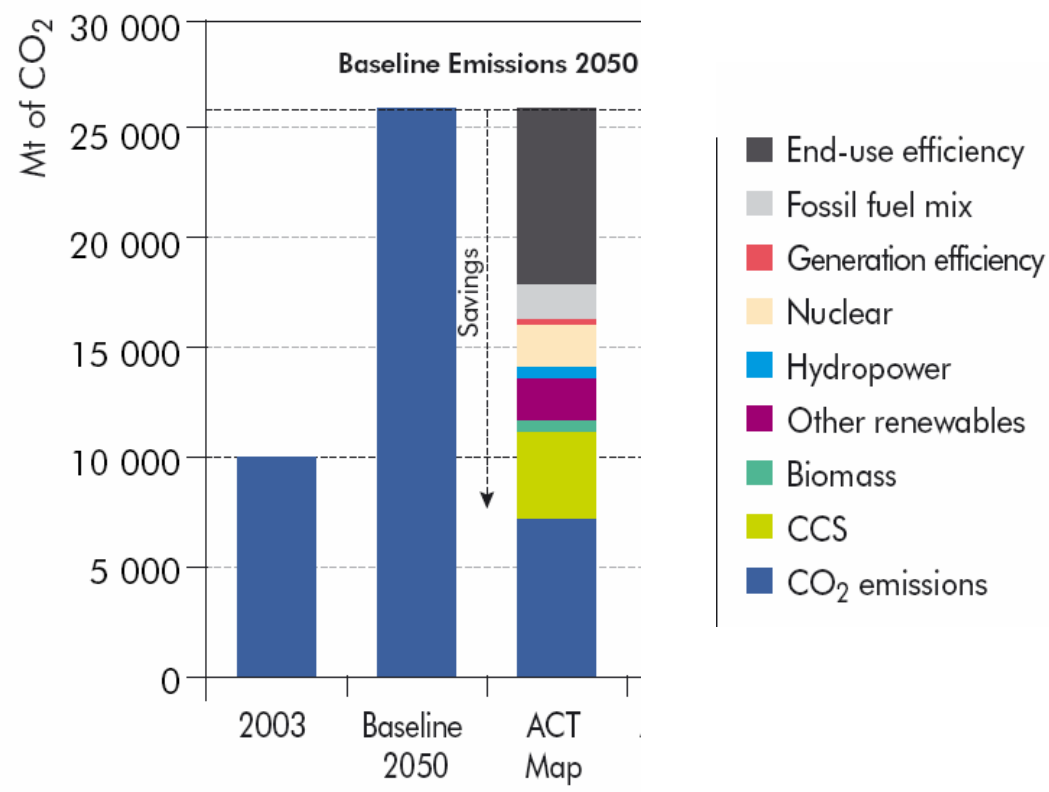


VIII. ADEQUACY OF R,D,\&D

IEA, ${ }^{61}$ Hawksworth, ${ }^{62}$ Morgan, ${ }^{63}$ MIT, ${ }^{64}$ and the author nine years ago, ${ }^{65}$ have observed that $\mathrm{R}, \mathrm{D}, \& \mathrm{D}$ funding in the energy area will need to be substantially increased in order for key technologies to be ready to reduce carbon dioxide emissions in a timeframe consistent with constraining atmospheric concentrations to protective levels. As illustrated earlier, the later a mitigation program is initiated, the more severe emission cuts must be if $\mathrm{CO}_{2}$ concentrations above 450 to $500 \mathrm{ppm}$ are to be avoided. ${ }^{66}$ Most recently, The Stern Report concluded: "support for energy R\&D should at least double, and support for the deployment of new low-carbon technologies should increase up to five-fold."

Figure 13, generated from IEA data, depicts world research expenditures in critical energy technology areas. ${ }^{68}$ Note the relatively flat funding in recent years, at a much lower level than expenditures in the 1975 to 1985 period which were in response to the Arab oil embargo. It is also noteworthy that Europe and Japan have been much more active in the nuclear research area, whereas the United States is the key player in coal-related research. ${ }^{69}$

It should be recognized that in the last few years, the United States has redirected some of its limited research resources to some key technologies, especially: hydrogen/fuel cells, IGCC, carbon capture and storage, and most recently biomass to ethanol technologies. ${ }^{70}$ The United States has coordinated its efforts in this

61. INT'L ENERGY AGENCY, supra note 13, at 32.

62. HAWKSWORTH, supra note 14 , at 58.

63. Granger Morgan, Jay Apt \& Lester Lave, The U.S. Electric Power Sector ANd Climate Change Mitigation ii (2005).

64. See MASS. InST. TECH., supra note 11, at xiii.

65. F. T. Princiotta, Renewable Technologies and Their Role in Mitigating Greenhouse Gas Warming, in AIR POLLUTION IN THE 21ST CENTURY: PRIORITY ISSUES AND POLICY 805 (T. Schneider ed., 1998).

66. See supra Figure 7.

67. Nicholas Stern, The Economics of Climate Change 348, STERN REVIEW (2006), available at http://www.hm-treasury.gov.uk/independent_reviews/stern_review_economics_ climate_change/stern_review_report.cfm.

68. INT'L ENERGY AGENCY, RD\&D BUDGETs, http://www.iea.org/RDD/TableViewer/ tableView.aspx?ReportId=1.

69. See INT'L ENERGy AGENCY, supra note 13, at 233-237.

70. See, e.g., Dep't. of Energy, U.S. Climate Change Technology Program: STRATEGIC PLAN passim (2006), available at http://www.climatetechnology.gov/stratplan/ final/CCTP-StratPlan-Sep-2006.pdf. 
area through the Climate Change Technology Program (CCTP). ${ }^{71}$ Within the constraint of current budget priorities, the CCTP has coordinated a diversified portfolio of advanced technology $R \& D$, focusing on: energy-efficiency enhancements; low-GHG-emission energy supply technologies; carbon capture, storage, and sequestration methods; and technologies to reduce emissions of non$\mathrm{CO}_{2}$ gases. $^{72}$ Also, the U.S. Environmental Protection Agency is implementing a series of voluntary programs which encourage greenhouse gas reduction. ${ }^{73}$ They include: Energy Star for the building sector, transportation programs, and non- $\mathrm{CO}_{2}$ emission reduction programs in collaboration with industry. ${ }^{74}$ These programs could provide a foundation for an expanded program, consistent with the mitigation challenge.

It is important to note that most of the non-coal technologies offer the potential for lower air emissions, water effluents, and waste generation residues. IGCC also offers the potential for such benefits; however, incorporating $\mathrm{CO}_{2}$ capture, transport, and storage substantially decreases overall plant efficiency, with the potential for commensurate increases in coal related pollution per unit of power generated. $^{75}$ Also, note that the transportation technologies all offer the potential for reducing our dependency on foreign oil. Further, the country or countries that can bring these technologies to market first have the potential for major revenue streams from what could be a huge international market.

71. Id. at 6 .

72. Dep't. of Energy, U.S. Climate Change and Technology Program: RESEARCH AND CURRENT ACTIVITIES, passim (2003), available at http://www.climatetechnology.gov/library/2003/currentactivities/car24nov03.pdf.

73. Environmental Protection Agency, Current and Near Term Greenhouse gas Reduction Initiative (2007), www.epa.gov/climatechange/policy/neartermghgreduction.html.

74. Id.

75. See MASS. INST. TECH., supra note 11 , at 30. 
Figure 13. World R,D,\&D expenditures (\$ millions) for key energy sectors, 2004

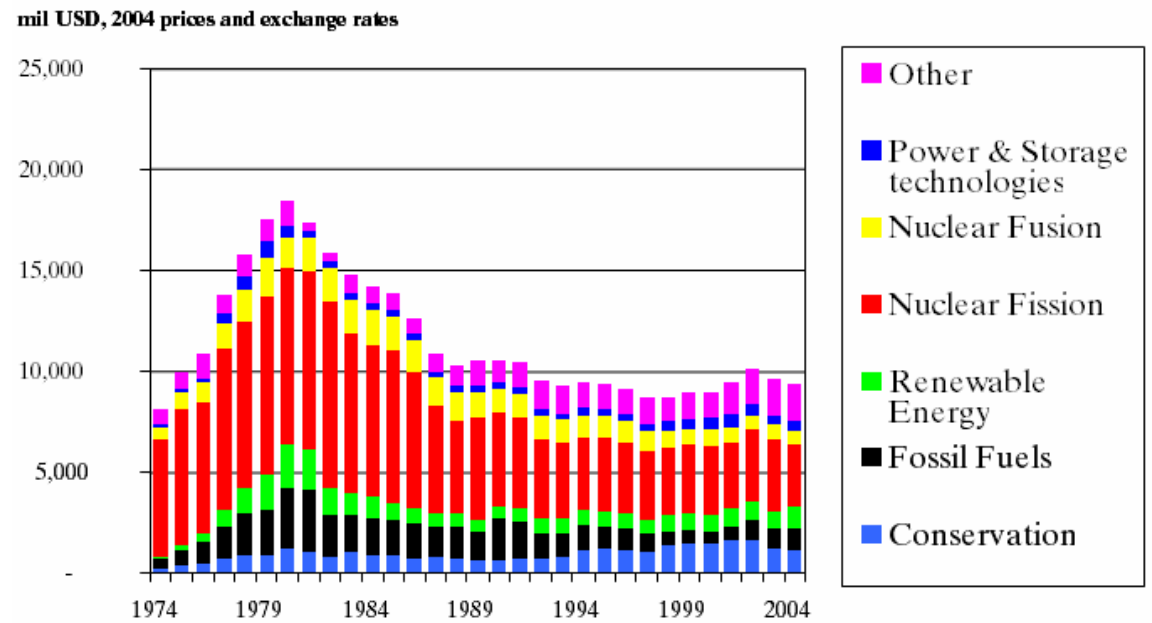

\section{SUMMARY AND CONCLUSIONS}

Atmospheric concentrations of $\mathrm{CO}_{2}$ have increased from a preindustrial level of $278 \mathrm{ppm}$ to $383 \mathrm{ppm}^{76}$ This increase is due to anthropogenic emissions of $\mathrm{CO}_{2}$ that can remain in the atmosphere more than 100 years. There is close to a scientific consensus that much, if not all, of the $0.8^{\circ} \mathrm{C}$ global warming that has occurred since the pre-industrial era is a result of increased concentrations of $\mathrm{CO}_{2}$ and other greenhouse gases.

Global emissions of carbon dioxide accelerated at a rate of about $1.4 \%$ per year in the 1992 to 2002 time period. However, recent data suggests an acceleration of emission growth to $3.2 \%$ in the 2000 to 2004 period. China's major expansion of its coal-fired power generation capacity has been a major factor in this unexpected spurt in growth rate.

Projections of global warming have been made based on a business-as-usual case or base case. This base case assumes a global annual growth rate of $1.6 \%$ in the next 25 years. Under this assumption, the atmospheric $\mathrm{CO}_{2}$ concentration is projected to increase to $500 \mathrm{ppm}$ in 2050 and $825 \mathrm{ppm}$ by $2100 .^{77}$ This will yield a

76. CAP AND SHARE, available at http://www.capandshare.org/ overlimit.html (last visited May 13, 2008).

77. Data derived using the MAGICC/SCENGEN modeling program; Princiotta, supra note 17. 
best-guess average warming, relative to 1990 , of $1.4^{\circ} \mathrm{C}$ in 2050 and $3.2^{\circ} \mathrm{C}$ in 2100 . There is still a large range of uncertainty associated with these warming projections; the potential warming in 2100 could be as high as $4.7^{\circ} \mathrm{C}$ or as low as $2.1^{\circ} \mathrm{C}$. This warming would be in addition to the $0.5^{\circ} \mathrm{C}$ already experienced from pre-1700 to 1990 . Warming would continue into the next century and beyond, with equilibrium temperatures in the 3.0 to $8.1^{\circ} \mathrm{C}$ range, with the best guess at $4.8^{\circ} \mathrm{C}$ above 1990 levels, assuming $\mathrm{CO}_{2}$ concentrations stabilized at $1000 \mathrm{ppm}$.

If current worldwide emission trends continue to surprise the prognosticators and grow at 3\% per year for the next 25 years, projected warming would be substantially higher. This scenario would yield a best-guess average warming, relative to 1990 , of $1.7^{\circ} \mathrm{C}$ in 2050 and $4.0^{\circ} \mathrm{C}$ in $2100{ }^{78}$ The potential warming in 2100 could be as high as $5.5^{\circ} \mathrm{C}$ or as low as $2.6^{\circ} \mathrm{C}$. $^{79}$ Warming would continue into next century, with equilibrium temperatures in the 3.4 to $9.0^{\circ} \mathrm{C}$ range, with the best guess at $5.4^{\circ} \mathrm{C} .^{80}$

It is too late to prevent substantial additional warming; the most that can be achieved would be to moderate the projected warming. The best result that appears achievable would be to constrain warming from 1990 to about $2^{\circ} \mathrm{C}$ (between 1.2 and $2.8^{\circ} \mathrm{C}$ ) by 2100 . Figure 6 illustrates that global impacts, even for this constrained warming scenario, are potentially serious. This suggests that the world community may have no remaining alternative other than to pursue adaptation approaches aggressively.

In order to limit warming to $2^{\circ} \mathrm{C}$, it will be necessary for the world community to decrease annual $\mathrm{CO}_{2}$ emissions at a rate of between 1 and $2 \%$ per year for the rest of the century. The earlier such a mitigation program starts, the less drastic the annual reductions would need to be. Since the base case assumes a roughly $1.5 \%$ positive growth rate, approximately one trillion tons of carbon (3.7 trillion tons of $\mathrm{CO}_{2}$ ) will have to be mitigated by 2100 relative to the base case. This will be a monumental challenge.

Recent publications were used to relate the implications of a one trillion ton mitigation program to the key energy sectors and the technologies within those sectors that could contribute to such a major mitigation challenge. The key energy sectors are power 
generation, transportation, industrial production, and buildings. The power sector and transportation sectors are particularly important, since they are projected to grow at relatively high rates, with China and India being key drivers.

The power generation sector, projected to grow from an already large base at a rate of $2 \%$ annually, offers the greatest opportunity for $\mathrm{CO}_{2}$ reductions. However, since the key source of emissions in this sector is coal combustion, it is critically important to develop affordable $\mathrm{CO}_{2}$ mitigation technologies for this source and to develop economical alternatives to coal-based power generation. CCS offers the potential to allow coal use while at the same time mitigating $\mathrm{CO}_{2}$ emissions. The three major candidates for affordable $\mathrm{CO}_{2}$ capture are: PC boilers with advanced $\mathrm{CO}_{2}$ scrubbing, IGCC with carbon capture, and oxy-fuel combustors. However, all three approaches rely on underground sequestration, an unproven technology at the scale required for coal-fired boilers, with many serious cost, efficacy, and safety issues. In addition, of the three, only IGCC is being funded at a level approaching that necessary for successful development. Alternatively, nuclear power plants, natural gas/combined cycle plants, and wind turbines all have the potential to decrease dependence on coal combustion and make significant contributions to $\mathrm{CO}_{2}$ avoidance. An accelerated $\mathrm{R}, \mathrm{D}, \& \mathrm{D}$ program is particularly important for advanced nuclear reactors, given their high mitigation potential, yet serious safety, proliferation, and waste disposal concerns.

If mitigation of three trillion tons of $\mathrm{CO}_{2}$ is deemed a serious goal, a major increase in $\mathrm{R} \& \mathrm{D}$ resources will be needed. Technology research, development, and demonstration are of particular importance for coal-based power generation technologies: IGCC, oxygen coal combustion, and $\mathrm{CO}_{2}$ capture technology for pulverized coal combustors. All of these technologies will have to be integrated with underground storage, a potentially breakthrough technology, but one which is at an early stage of development. Also important are next generation nuclear power plants.

Given the monumental challenge and uncertainties associated with a major mitigation program, the author believes it prudent to consider all available and emerging technologies. This suggests that fundamental research on energy technologies in addition to those in Table 1 be part of the global research portfolio, since breakthroughs on today's embryonic technologies could yield tomorrow's alternatives. 
Finally, availability of key technologies will be necessary but not sufficient to limit $\mathrm{CO}_{2}$ emissions. Since many of these technologies have higher costs and/or greater operational uncertainties than currently available carbon intensive technologies, robust regulatory/incentive programs will be necessary to encourage their utilization. 